understanding of savings and credit behavior as part of a different and changing relational and broader contexts, based on new social-scientific challenges, problem statements and insights. For registration and submission information visit: Website:www.sls.wau.nl/law/livelihoodsavingsdebt; and www.sls.wau.nl/livelihoodsavingsdebt.

\section{MEETING CALENDER}

\section{THE AMERICAN ASSOCIATION FOR HISTORY AND COMPUTING}

The American Association for History and Computing presents its 2001 Annual Meeting. The theme is: "Moving Clio into the New Millennium:Interaction, Visualization, Digitization, and Collaboration." University and college instructors, K-12 teachers, librarians, publishers, editors, archivists, interpreters, students, software developers, and all other history professionals are encouraged to participate. For further information contact: Dennis Trinkle, Executive Director, American Association for History and Computing, Department of History, DePauw University, Greencastle, IN 46135; Email: dennis.trinkle@theaahc.org;orKen Dvorak, Secretary/Treasurer, American Association for History and Computing, 17250 Logans Run,Battle Creek, Michigan, 49014;Email:dvorakkr@aol.com; Website:theaahc.org.

\section{UNIVERSITY OF MUMBAI}

The Center for African Studies, University of Mumbai (Bombay) is planning a three day international seminar in February 2001. The theme is "Indian Ocean Island States and the Littoral: Conflict and Cooperation." The seminar is designed to cover developments in the area geographically ranging from Cape of Good Hope to Indonesian archipelago within a global perspective. For further information contact: V.S. Sheth, Director of The Center for African Studies, University of Mumbai (Bombay), Bombay, India; Fax: 0091-226526893.

\section{LIBERIAN STUDIES ASSOCIATION}

The 33rd Annual Meeting of the Liberian Studies Association is May 13 - 152001 in Tel Aviv University, Israel. The theme is "Liberia, Africa and the International Community." For more information contact: ProfYekutielGershoni, Department of Middle Eastern and African History, Tel Aviv University, Tel Aviv 69978, Israel; Email: gygygy@post.tau.ac.il.

\title{
EMPLOYMENT OPPORTUNITIES
}

\section{RESEARCH ASSISTANT}

The Metropolitan Museum of Art is seeking a part-time Research Assistant to assist with research centering on the permanent collections and special exhibitions of arts of Africa, Oceania and the Americas, both inside the Museum and for outgoing loans. The candidate will supervise the cataloguing of African collections in both card and electronic form. Candidates are required to have an M.A. degree in art history with specialization in African art. Reading knowledge of French is necessary, German helpful. For further information and to submit application contact: The Metropolitan Museum of Art, Human Resources, Box TS AAOA, 1000 Fifth Avenue, New York, NY 10028.

\section{EXECUTIVE SECRETARY}

The Council for the Development of Social Science Research in Africa (CODESRIA), based in Dakar, Senegal, invites applications from African Social Science scholars for the position of Executive Secretary. The Executive Secretary is responsible for coordinating the writing of proposals for various programs, funding requests and research reports; providing intellectual leadership to research networks activities; promoting the establishment of professional associations; and organizing and facilitating scientific round tables, meetings and conferences in Africa. The candidate is required to have experience in research formulation, guidance, coordination and research reporting, have knowledge of CODESRIA and/or similar research organizations, possess management and administrative experience in similar research organizations with experience and credibility in fund-raising. A working knowledge (oral and written) of both French and English is necessary. Candidates should submit an application letter, a detailed curriculum vitae including training and professional experience, three reference letters from people who know the applicant's work (including at least two resident in countries other than those of the applicants), one copy of three or four of applicant's own publications. Reference letters should be sealed and sent directly to CODESRIA. The application deadline is November 15, 2000. If interested, send correspondence labeled "APPLICATION" to: The President of the Executive Committee, CODESRIA, BP 3304, Dakar, Senegal.
ASSISTANT PROFESSOR

The Women's Studies Department at the University of California-Berkeley invites applicants for a full-time Assistant Professor in Gender and Political Economy in a Global Context. The position is a tenure-track position beginning July $\mathbf{1}$, 2001. Send a cover letter, c.v., a short writing sample, and three letters of recommendation by November 1, 2000 to: Caren Kaplan, Chair, Department of Women's Studies, 3326 Dwinelle \#1070 ,University of California-Berkeley, Berkeley, CA 947201070; Tel: (510) 642-8513.

\section{ASSISTANT PROFESSOR}

The Department of Art History at the University of California-Santa Cruz, invites applications for a tenure-track position as Assistant Professor specializing in study of the visual cultures of Africa and/or the African Diaspora. The position is available July 1, 2001. Candidates with Ph.D. or advanced $\mathrm{Ph} . \mathrm{D}$. candidate in a relevant field of study are preferred. Letters of application should address scholarly background, current work, and future research plans. Application materials consist a writing sample; descriptions of three courses; list of three references from whom the applicant has requested confidential letters of recommendation. Please submit all materials by December 15, 2000 to: Africa Search Committee Department of Art History, Porter Faculty Services, University of California, $1156 \mathrm{High}$ Street Santa Cruz,CA 95064;.Website: www2.ucsc.edu lahr/academic.html.

\section{ASSISTANT PROFESSOR}

The College of Arts and Sciences at the University of San Francisco invites applications for a Assistant Professor tenure-track position in Anthropology, Communication Studies, Fine and Performing Arts, History, Media Studies, S o c i ology, or Theology/Religious Studies with speciality in African studies. The position is available in the Fall 2001, pending approval and funding. Teaching responsibilities may include lower and upper division courses centered on Africa as well as in the candidate's area of specialization. The candidate is expected to have university teaching experience, evidence of a strong commitment to teaching, evidence of scholarship, and an earned doctorate by Fall 2001. Applicants are asked to submit a letter of application, curriculum vitae, graduate transcripts, copies of recent publications, statement of teaching philosophy, evidence of teaching ability including copies of complete teaching evaluations, and three let- 